\title{
Avaliação de 4 currículos de Odontologia baseada em expectativas e satisfação de alunos - relato de experiências norueguesa e brasileira
}

Cassiano Kuchenbecker Rösing*, Débora Trevisan da Silva**, Patrícia Deon***, Rui Vicente Oppermann****, Per Gjermo*****

* PhD, Associate Professor of Periodontology, Federal University of Rio Grande do Sul and Lutheran University of Brazil, Brazil

** DDS, Dental Student, Lutheran University of Brazil, Brazil

*** DDS, MSD, Lutheran University of Brazil, Brazil

**** PhD, Professor of Periodontology, Federal University of Rio Grande do Sul, Brazil

***** $\mathrm{PhD}$, Professor Emeritus, University of Oslo, Norway

\section{RESUMO}

O objetivo desse estudo foi avaliar quarto currículos odontológicos (dois no Brasil e dois na Noruega), baseado em satisfação de estudantes e professores. Questionários estruturados foram confeccionados. Essa pesquisa foi realizada durante uma mudança curricular de uma abordagem tradicional (orientada por disciplina) para uma forma integrada, com aprendizado baseado no problema. Ambos os currículos brasileiros eram tradicionais. Vinte e dois alunos do currículo ântico (UiO-antigo) e 17 estudantes do novo currículo em Oslo (UiOnovo) e 25 alunos de cada universidade brasileira (UFRGS e ULBRA) foram incluídos. Líderes de disciplinas nas Universidades também participaram (UiO, $\mathrm{n}=17$, UFRGS, $\mathrm{n}=10$, ULBRA, $\mathrm{n}=13$ ). A maioria dos alunos e professores tiveram a opinião de que seu currículo habilita os dentistas para trabalhar combinadamente em práticas públicas e privadas, em todo o mundo. Independentemente do currículo, os alunos apontaram dúvidas sobre sua competência em realizar próteses fixas amplas, orthodontia complexa, colocação e manutenção de implantes, tratamento de desordens crânio-faciais e planejamento de programas de saúde pública. A avaliação da qualidade do ensino teórico e clínico revelou que a maioria dos estudantes está satisfeita. Como avaliação geral, uma EVA (escala visual analógicafoi aplicada para avaliar satisfação de alunos e professores. Os resultados não demonstraram diferenças estatisticamente significativas (ANOVA, $\alpha=0.05)$ entre estudantes (7.12, 7.36, 6.8 and 6.8) para UiO-antigo, UiO-novo, UFRGS e ULBRA, respectivamente. Pode-se concluir que algumas diferenças culturais puderam ser detectadas entre Noruega e Brasil, e que professorees que estavam vivenciando a alteração curricular apresentaram maior satisfação com a nova abordagem.

\section{DESCRITORES}

Educação Odontológica. Desenvolvimento de Currículo. Competência. Expectativas. Satisfação.

D) ifferences in dental education among diverse geographical parts of the world, reflecting cultural, socioeconomic and behavioral aspects in the process of learning and teaching are the core of the different approaches in education. Also, the changes in the prevalence of oral diseases have led to different approaches in dental education.

Norway and Brazil are two countries with differences in culture, social structure, educational systems and the epidemiology of oral diseases. Although experiencing a decrease in the prevalence of oral diseases, a number of Dental Faculties has been created in Brazil. Data from 2000 have reported more than 130 Schools of Dentistry in Brazil ${ }^{2}$ with an outcome of approximately 10000 dentists graduated per year. 
The consequences of this high number of professionals trained are still unknown and might have an impact on the dental students' expectations and satisfaction. On the other hand, with a smaller territory and less population density, Norway has only 2 Faculties of Dentistry, producing approximately 100 dentists per year. ${ }^{8}$ The scenario of Dentistry is very different in these two countries. In Brazil, the emphasis is on private practice, while in Norway it is a well-developed public dental care system, employing approximately $1 / 3$ of the dentists.

All the dental education given in Norway is public (state provided). In Brazil, there are two University systems: one is governmental and the other is private. Throughout the history, the private education sector has gained more and more space as the budgets for governmental education have been reduced. ${ }^{2}$

Changes in society, patient needs, pedagogic methods and knowledge on dental treatment would call for changes in the dental curricula. Therefore, evaluating the performance of dental curricula is a way of continuously updating the educational process. Expectations and satisfaction with dental curricula have been reported from several institutions. ${ }^{1,5,9,10}$

In 1996, the University of Oslo, Norway (UiO) changed its curriculum from a traditional to a selforiented, problem-based and discipline integrated training program. The new curriculum was introduced as the students starting in 1995 continued on the old curriculum. In Brazil, mainly traditional discipline-oriented curricula are being used, similar to the old curriculum at $\mathrm{UiO}$.

At Universities in western industrialized countries the pedagogic principles have changed during the last decades. The traditional teacher dominated, lecture based teaching has been substituted for a mutual, bi-directional learning process. This has emerged from questioning the role of the teachers as the only leaders and responsible for education rather than being co-participants. Promising results have been reported from medical fields. Problem Based Learning (PBL) has been introduced in order to integrate theory and practice, and also to have other sources of information than the teacher. Satisfaction has been used to measure how the process has been accepted. $(3,4,6,7,8)$

We have performed a study about dental curricula in terms of how students perceive some aspects of their education and how they utilize the options for learning offered (9). In this respect we observed that there are differences between the two countries as well as between the two dental curricula in Norway. The objective of the present study was to evaluate Norwegian and Brazilian students' expectations and satisfaction with the curriculum they are undergoing. Some information gathered from the teachers is also reported.

\section{MATERIALS AND METHODS The Study Populations}

The study populations of this investigation comprised students from the three Dental Schools included in the project. The students from $\mathrm{UiO}$ were subdivided in accordance to the curriculum they were under (old or new). The selection of the students was made according to convenience (availability to answer the questionnaire). The number of each group is depicted in Table 1.

The teachers participating in the investigation were the leaders of disciplines in each Dental School and were evenly distributed in terms of basic sciences and clinical disciplines.

\section{Methods}

A questionnaire with open and closed questions was constructed, concerning expectations and satisfaction. Expectations included broadness of the curricula, working plans after graduation and expected ability to perform clinical procedures. Satisfaction comprised perceptions on quality of theoretical activities and clinical guidance, as well as an overall opinion. In a pilot study among students from all involved institutions not participating in the original study, the final format of the questionnaire was developed. This was done in order to avoid misunderstandings. The questionnaire was applied by one of the authors who could guide the respondent if necessary (in Portuguese or Norwegian as applicable). The teachers went through a structured interview based on the questionnaire.

Table 1 - Study Populations.

\begin{tabular}{|c|c|c|c|}
\hline \multirow{2}{*}{ Curriculum } & \multicolumn{2}{|c|}{ Number of students } & Number of \\
\cline { 2 - 3 } & Interviewed & Total & teachers \\
\hline UiO - Old & 22 & 45 & $17^{\star}$ \\
\hline UiO - New & 28 & 30 & $17^{\star}$ \\
\hline UFRGS & 25 & 40 & 10 \\
\hline ULBRA & 25 & 51 & 13 \\
\hline
\end{tabular}

* The same teachers were interviewed about both curricula. 


\section{Analysis of the data}

The descriptive data from this study were reported as $\%$ of answers of selected questions. For the overall evaluation of the curricula based on satisfaction, a Visual Analogue Scale (VAS) was used with information on the left end "the worst curriculum one can imagine" and in the right end "the best curriculum possible". Mean VAS values were obtained for each group of students and to these data, ANOVA was applied $(\alpha=.05)$.

\section{RESULTS}

\section{Expectations}

Graph 1 shows the broadness of the different curricula as perceived by the students. The Brazilian students were more polarized about their education as compared to the Norwegians. A larger percentage of the Brazilians think that they have either qualification to act within their country only, or worldwide. The $\%$ of students having the opinion of being able to act worldwide is not very different among students in the 4 curricula. On the other hand the teachers' opinion (Norwegians and Brazilians) were similar to those of the Brazilian students' (data not shown).

Graph 2 reveals the future working plans of the dental students. Although a large proportion of students from all curricula was planning to combine private and public practice, the majority of the Brazilian students preferred the combination. It is important to note that there is a very small percentage of Brazilians that have the objective of working in public health only. From the Lutheran University of Brazil (ULBRA) (the private University), no one has demonstrated any interest in working at the Public Health System solely.

Table 2 demonstrates a set of different clinical procedures and the data were reported in terms of proportions of students and teachers that positively answered the question, showing their expectation of having the knowledge and ability to perform these procedures after graduation. A pattern can be observed among the 3 Dental Faculties. First, complex orthodontics and treatments involving placement and maintenance of implants are procedures that are not included in the 4 evaluated curricula. Also, students from ULBRA have the opinion that they are not able to perform extensive fixed prosthodontics and treatment of TMJ disorders. Among the majority of the other students this seems to be within their expectations. Periodontal surgery was not expected to be performed by students from the Federal University of Rio Grande do Sul (UFRGS) and complex amalgam restorations by the students from ULBRA. Simple orthodontics was included in the middle range by
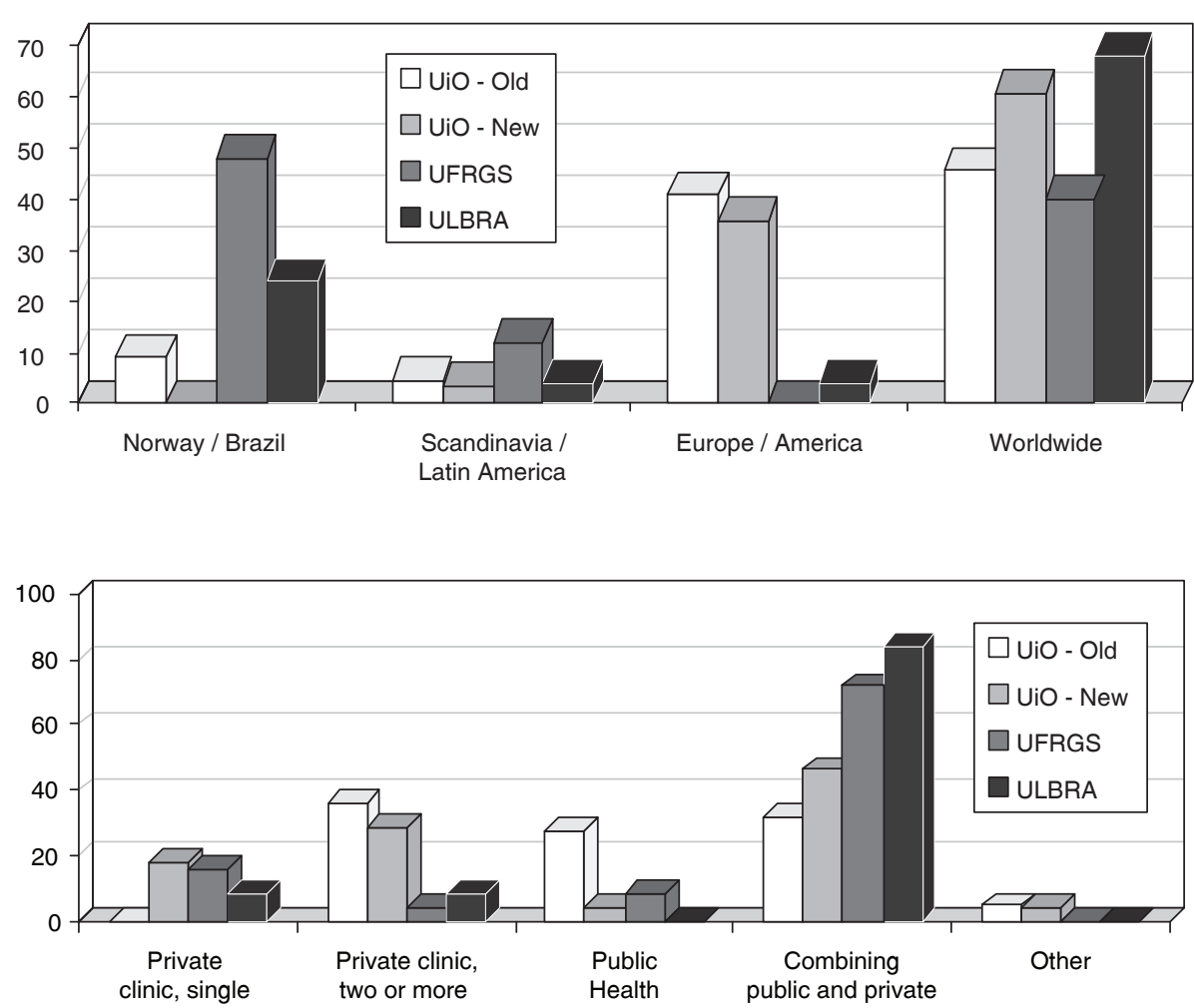

Graph 1 - Do you think your education enables you to work within an oral health system in:
Graph 2 - After graduation, where/how do you intend to work? 
Table 2 - Students' and teachers' opinion about qualification for different clinical procedures after graduation.

\begin{tabular}{|c|c|c|c|c|c|c|c|}
\hline & $\begin{array}{l}\text { Students } \\
\text { UiO - Old }\end{array}$ & $\begin{array}{l}\text { Students } \\
\text { UiO - New }\end{array}$ & $\begin{array}{l}\text { Students } \\
\text { UFRGS }\end{array}$ & $\begin{array}{l}\text { Students } \\
\text { ULBRA }\end{array}$ & $\begin{array}{l}\text { Teachers } \\
\text { UiO }\end{array}$ & $\begin{array}{l}\text { Teachers } \\
\text { UFRGS }\end{array}$ & $\begin{array}{l}\text { Teachers } \\
\text { ULBRA }\end{array}$ \\
\hline Supragingival scaling & * & * & * & * & $\S$ & * & * \\
\hline Subgingival scaling & * & * & * & * & $\S$ & * & * \\
\hline Periodontal surgery & * & * & $\S$ & * & \# & $\#$ & \# \\
\hline Complex Amalgam Restorations & * & * & * & $\S$ & $\#$ & $\S$ & $\#$ \\
\hline Regular Amalgam Restorations & * & * & * & * & $\S$ & $\S$ & * \\
\hline Complex Composite Restorations & * & * & * & * & $\S$ & $\S$ & $\S$ \\
\hline Regular Composite Restorations & * & * & * & * & $\S$ & * & * \\
\hline Complete Dentures & * & * & * & * & $\#$ & * & $\S$ \\
\hline Partial Removable Dentures & * & * & * & * & $\#$ & * & * \\
\hline Fixed Crowns & * & * & * & * & $\S$ & * & $\S$ \\
\hline Bridges up to 3 elements & * & * & * & * & $\S$ & $\#$ & $\S$ \\
\hline Bigger bridges & $\S$ & $\S$ & $\S$ & $\#$ & $\#$ & $\#$ & $\S$ \\
\hline Endodontics in single-rooted & * & * & * & * & $\S$ & * & * \\
\hline Endodontics in multi-rooted & * & * & * & * & $\S$ & * & $\S$ \\
\hline Simple orthodontics & $\S$ & * & * & $\S$ & $\#$ & $\S$ & $\S$ \\
\hline Complex orthodontics & $\#$ & $\#$ & $\#$ & $\#$ & $\#$ & $\#$ & $\#$ \\
\hline Implant placement & $\#$ & \# & \# & \# & \# & $\#$ & $\#$ \\
\hline Implant maintenance & $\#$ & \# & \# & $\#$ & $\#$ & $\#$ & $\#$ \\
\hline Treatment of deciduous teeth & * & * & * & * & $\S$ & * & * \\
\hline Treatment of the elderly & * & * & * & $\S$ & $\S$ & $\S$ & $\#$ \\
\hline Minor oral surgery & * & * & $\S$ & $\S$ & \# & * & $\S$ \\
\hline Treatment of TMJ disorders & * & $\S$ & $\S$ & \# & $\S$ & $\S$ & \# \\
\hline Diagnosis of mucosal lesions, cancer, etc. & $\S$ & * & * & * & $\#$ & * & $\S$ \\
\hline $\begin{array}{l}\text { Planning and execution of a community } \\
\text { dentistry program }\end{array}$ & $\S$ & $\S$ & $\S$ & $\S$ & $\S$ & $\S$ & $\S$ \\
\hline
\end{tabular}

* $>70 \%$ of positive answers. $§ 30-70 \%$ of positive answers. \# $<30 \%$ of positive answers.

Graph 3 - How do you rate the quality of the theoretical activities?

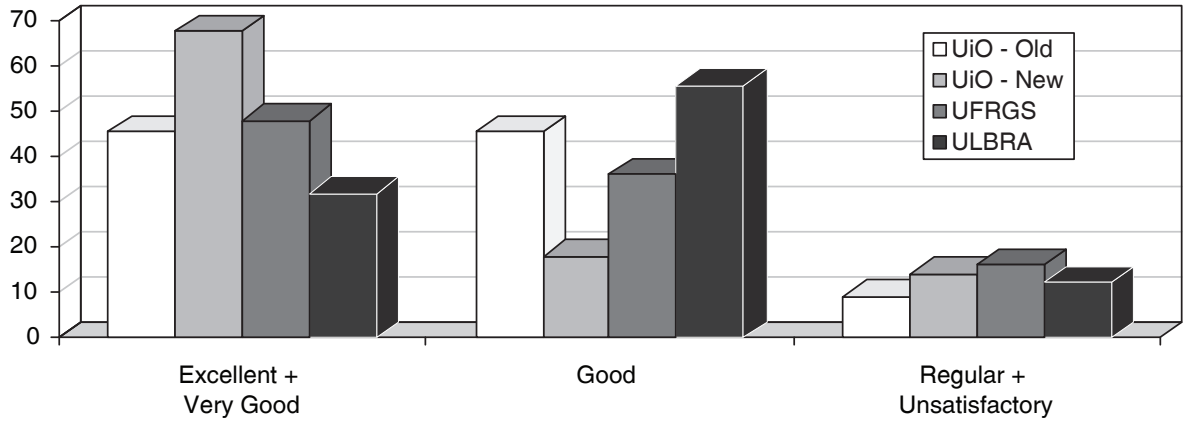

students from UiO - old curriculum and ULBRA. Treatment of TMJ disorders had a similar appreciation from students from the new curriculum in Oslo and from UFRGS. The Brazilians were not so comfortable in performing minor oral surgery. A remarkable finding is that planning and execution of a community dentistry program did not seem to be wi- thin the expectations of the students regardless of the curriculum. The other procedures had a frequency of more than $70 \%$ of positive answers by the students, probably indicating a positive expectation on the capacity of performing them.

The teachers considered the same kind of procedures the most unlikely to be performed by the stu- 


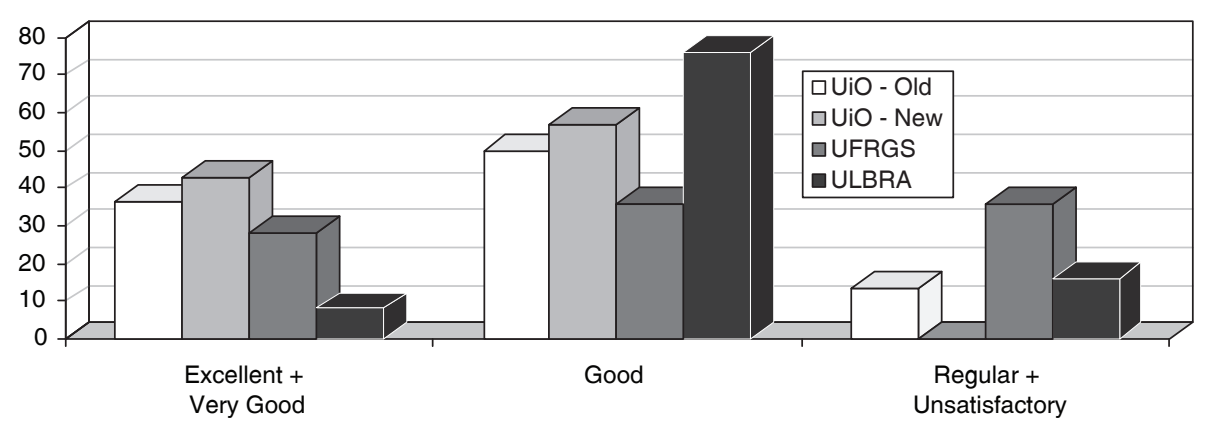

Graph 4 - How do you rate the quality of the clinical guidance? dents. For virtually all procedures, the teachers were more pessimistic with the performance of their students than the students themselves. No procedure was considered performable by the students by more than $70 \%$ of the Norwegian teachers. More than $70 \%$ of the Brazilian teachers from both Universities considered that supra and subgingival scaling, regular composite restorations, partial removable dentures and endodontics in single-rooted teeth can be performed by the graduates (Table 2).

\section{Satisfaction}

The perceived quality of the theoretical and practical activities in dental education is shown in Graphs 3 and 4 . Very few students considered the teaching either excellent or unsatisfactory. Thus, these results were merged with the adjacent categories. Most students in the 4 evaluated curricula considered the quality of the theoretical activities from good to very good. One student at the $\mathrm{UiO}$ - new curriculum and one at UFRGS considered them excellent. On the other hand, one student in each Norwegian group and 2 at UFRGS considered the quality of the theoretical activities unsatisfactory. Different patterns of satisfaction with this topic cannot be detected clearly. It looks like there is a somewhat better satisfaction with theoretical activities among the Norwegians in the new curriculum. The teachers reported a similar pattern as the students (data not shown).

The quality of clinical guidance has also been surveyed (Graph 4), and the same evaluation as for the theoretical activities was found. Only 2 students from UFRGS considered them excellent and two from the same University considered them unsatisfactory. It seems that the Brazilians display a higher degree of disappointment with their clinical guidance.

A quantification of the overall opinion on a Visual Analogue Scale was performed and is shown in Table 3. No statistically significant differences could be detected.
Table 3 - Overall opinion about the curriculum based on a Visual Analogue Scale (mean \pm s.d.).

\begin{tabular}{|c|c|c|c|c|c|}
\hline & UiO - Old & UiO - New & UFRGS & ULBRA & Sig. \\
\hline Mean & 7.12 & 7.36 & 6.8 & 6.8 & n.s. \\
VAS (s.d.) & $(1.35)$ & $(1.37)$ & $(1.55)$ & $(1.22)$ & \\
\hline
\end{tabular}

n.s.: not statistically significant - ANOVA, $p>0.05$

\section{DISCUSSION}

Student's satisfaction has previously been studied by Farge et al. (5). They compared satisfaction of students from the old and new curricula at the Faculty of Dentistry in Lyon, France, in a similar way as in the present study. Widström et al. (6) studied students' satisfaction in the Nordic countries. We made an attempt also to compare the 2 curricula at $\mathrm{UiO}$ with one public and one private University in Brazil. Questionnaires seem to be an adequate tool in these kinds of investigations $(2,4,6)$.

The first part of our study concerns expectations of the students in relation to some aspects after their graduation. The students from Norway had a more broad perspective in terms of their qualification. Among Brazilians, the opinion was either only countrywise or worldwide. Most of the Norwegians students considered themselves able to work either in whole Europe or worldwide. This may be explained by the Brazilian dental degrees being valid only domestically, while the Norwegian Dental degree is valid within the European Union (EU). Dental curricula and the teacher's background in northern Europe have been investigated and did not show many differences $(6,10)$.

In Brazil, there was a tendency that more students intended to work in both public health and private. Considering that public dental health system is poorly developed in Brazil and hardly can provide work for all those who want, this feature might facilitate a future improved public oral care. However, Brazilian students showed very little interest in working in pu- 
blic health only. This might probably reflect the poor expectations in terms of salaries in these positions.

In Norway, we observed that students from the old curriculum, who are almost to graduate, displayed a wide variety of future plans. Working in a private clinic alone was not chosen by anyone. In Norway such practices are gradually replaced by larger clinics offering more professional stimulation in daily contact with colleagues. Also, the expenses involved in starting a new practice may influence this decision. There was also a difference between old and new curricula in terms of the experience they had been through. The students from the old curriculum had already been in the field at public dental clinics, and there were a larger number of them willing to work either in public or combining public and private. In the new curriculum, there was still a part of them willing to work in a single private practice. The evolution of their education might make their opinion change, since they have 2 more semesters to decide (6). The results from another study in Norway confirm that the closer the dental students get to their graduation, expectations tend to change (11). The same students from the new curriculum at $\mathrm{UiO}$ who participated in our investigation took also part in this study. In their last semester, approximately half of them would have the public health sector as their first job opportunity, similar to what we detected for the students from the old curriculum at $\mathrm{UiO}$.

We also tried to detect expectations by means of students' and teachers' perceptions of capability to perform different clinical procedures, assuming that students from the last year had a realistic idea of which procedures they could and could not perform. Basically the 4 curricula did not differ in this respect. The procedures considered more difficult to perform after graduation were the ones that are normally performed by specialists such as dental implants and orthodontics. On the other hand, some procedures such as large bridgework, treatment of TMJ disorders and planning and execution of a community program, the majority of students, regardless of their origin, did not classify as performable. Other procedures were also in the list of the difficult ones, but with no clear-cut pattern. Similar results were found in the evaluation performed in Australia and Canada of self-perceived competency after graduation (3).

Teachers have a totally different view than the dental students. Their evaluation in this respect was much less positive. The Norwegian teachers expressed the most pessimistic view. This may be a cultural differen- ce, either in the way teachers perceive student's capacity, or in the sense that they are always aiming for more quality.

In terms of satisfaction, we could not find any notable difference between the 4 curricula studied. We can pick from the results that they are reasonably satisfied with their theoretical training and with the clinical guidance. It was surprising not to find larger differences between the new and old curricula in $\mathrm{UiO}$, considering the substantial changes that had taken place. Introduction of PBL has been studied in different places and some anxiety comes with it (11). Apparently, this was not observed in the $\mathrm{UiO}$, although the students were already in their $8^{\text {th }}$ semester.

A visual analogue scale was constructed to try to quantify satisfaction with the 4 dental curricula. These types of scales have been used in trying to quantify parameters that are not directly measurable. No differences could be observed for the 4 curricula. This may reflect that the students were well satisfied. One can argue that this opinion is biased, since the students have been subjected to only one type of curriculum. However, the timing of the study in Oslo should be suitable, since we had students in both curricula at reasonably similar levels. However, the nature of the VAS may not be suited to evaluate a total satisfaction with a curriculum, since this is composed of many elements and the judgements will tend to express similar means. Thus, the different questions described above are probably a better way to disclose the students' satisfaction with separate parts of the curriculum.

We can conclude that the 4 different curricula, in 2 different countries tend to create similar expectancies and satisfaction in students. Regarding capability of performing clinical procedures, teachers tend to be more pessimistic than do the students.

\section{ABSTRACT}

Evaluation of 4 dental curricula based on students' expectations and satisfaction - report of Brazilian and Norwegian experiences

The aim of this study was to evaluate four dental curricula (two in Norway and two in Brazil), based on students' and teachers' satisfaction. Structured questionnaires were constructed. This investigation was performed during a change in the curriculum from a traditional approach (discipline oriented) to an integrated, problem-based learning approach. Both of the Brazilian curricula were traditional. Twenty-two students from the old curriculum ( $\mathrm{UiO}-$ old) and 17 
students from the new curriculum in Oslo ( $\mathrm{UiO}-$ new), and twenty-five students from each Brazilian university were included (UFRGS and ULBRA). Leaders of disciplines in the universities also participated (UiO, n=17, UFRGS, n=10, ULBRA, n=13). Most students and teachers had the opinion that their curriculum enabled dentists to combine public and private practices and to work worldwide. Regardless of curriculum, the students reported doubts about their competence in performing large fixed prostheses, complex orthodontics, placement and maintenance of implants, treatment of craniofacial disorders and planning of community oral health programs. The evaluation of the quality of the theoretical and clinical guidance revealed that the students were mostly satisfied. As an overall evaluation, a VAS (Visual Analogue Scale) was applied to assess students' and teachers' satisfaction. The results did not show any statistically significant difference (ANOVA, $\alpha=.05$ ) among students $(7.12,7.36,6.8$ and 6.8) for $\mathrm{UiO}$ - old, $\mathrm{UiO}$ new, UFRGS and ULBRA, respectively. We concluded that some culturally dependent differences between Norway and Brazil could be detected, and that teachers who were in the process of changing a curriculum expressed higher satisfaction with the new approach.

\section{DESCRIPTORS}

Dental Education. Curriculum Development. Competency. Expectations. Satisfaction.

\section{REFERENCES}

1. Farge P, Virieux J, DouryJ. Student satisfaction with curriculum modifications in a French dental school. EurJ Dent Educ 2000: 4: 112-117.

2. Federal Council of Dentistry, Brazil. www.cfo.org.br

3. Fiehn N-E. The basic science teaching experience in the Nordic countries. Eur J Dent Educ 1998: 2: 115-123.

4. Greenwood F, Townsend G, Joseph V, Wetherell J. Introducing Adelaide dental students to a problem-based learning curriculum. Eur J Dent Educ 1999: 3: 15-19.

5. Greenwood LF, Townsend GC,Wetherell JD, Mullins GA. Selfperceived competency at graduation: a comparison of dental graduates from the Adelaide PBL curriculum and the Toronto traditional curriculum. Eur J Dent Educ 1999: 3: 153-158

6. Lum-Peng L, Ai-Yen, C. Challenges and relevance of problembased learning in dental education. Eur J Dent Educ 1999: 3: 20-26.

7. Neufeld VR, Barrows HS. The Mc Master Philosophy: an approach to medical education. J Med Educ 1974: 20: 267-273.

8. Norwegian Dental Association, Norway. www.tannlegeforeningen.no

9. Pau AKH, Collinson S, Croucher R. Dental students' evaluation of 2 community-oriented PBL modules. Eur J Dent Educ 1999: 3: 159-166.

10. Widström E, Birn H, Haugejorden O, Martinsson T. Dental student's views on their education and study circumstances in Nordic countries. Swed Dent J 1990: 14: 115-122. 